\title{
Çevreye Duyarlılık Ve Sorumluluk Bağlamında Yeşil Halkla İlişkiler Ve Antroposen Kavramı: Billboardlar Üzerinden Bir Göstergebilimsel Analiz
}

DOI: 10.26466/opus.791359

\author{
Mustafa Akdağ ${ }^{*}$ - Merve Özdemir** \\ * Prof. Erciyes Üniversitesi, İletişim Fakültesi, Kayseri/Türkiye \\ E-Posta: makdag42@gmail.com \\ ORCID: $0000-0002-1818-2960$ \\ ** Öğretim Görevlisi, Kapadokya Üniversitesi, Kapadokya MYO, Nevşehir/Türkiye \\ E-Posta: merve.ozdemir@kapadokya.edu.tr～ORCID: 0000-0001-9169-3807
}

\begin{abstract}
$\ddot{O} z$
Küreselleşme ile insan merkezli bir hale gelen gezegenin ekolojik açıdan tahrip edilmesi son dönemde birçok disiplin tarafindan ele alınan bir konudur. Ekolojik dengenin bozulması ile gündeme gelen antroposen, özellikle insanın dünya üzerindeki tahribatını ele alan bir kavramdır. Sanayi devrimi ile beraber artarak devam eden fosil yakıt kullanımı, atmosferdeki sera gazı etkisini artırarak küresel ısınmayı önemli ölçüde etkilemektedir. Dolayısıyla küresel ısınma etkisinin artması dünyanın bir yaşam alanı halinden oldukça uzaklaştığını göstermektedir. Bütünleşik bir yapı gerektiren ekoloji, işletmelerin de bu anlamda adım atmasını zorunlu kılmaktadır. Küreselleşme ve rekabet ortamının artması ile işletmeler, halkla ilişkiler, sosyal sorumluluk, reklam, pazarlama ve marka çalışmalarını sürdürülebilir yeşil felsefe üzerine temellendirerek hem toplumun hem de makro anlamda gezegenin sürdürülebilirliğine katkı sağlayacak özne konumundadır. İşletmelerin tamamen kar odaklı bir felsefe benimsemeyip çevreye duyarlı sorumluluk projeleri geliştirmeleri küresel çevre sorunlarına karşı önleyici bir adım attıkların göstermektedir. Bu da bilinçli hale gelen günümüz tüketicisinin marka tercihini önemli ölçüde etkilemektedir. Bu bağlamda işletme ile tüketici arasında bir köprü görevi gören yeşil halkla ilişkiler çalışmaları, yapılacak iletişimsel çalışmaları önemli bir ayağını oluşturmaktadır. Bu anlamda çalışma içerisinde halkla ilişkiler araçlarından olan billboard projelerine yer verilerek göstergebilimsel bir analiz konu dahilinde incelenmiş ve yapılan çevreci billboard faliyetlerinin hem sürdürülebilirliğe katkı sağladığı hem de tüketiciler tarafindan daha fazla tercih edildiği dikkat çekmiştir.
\end{abstract}

Anahtar Kelimeler: Yeşil Halkla İlişkiler, Antroposen, Çevresel Duyarllık ve Sorumluluk, Çevre Sorunlar, Billboard 


\title{
Green Public Relations And Antropocene Concept In The Context Of Environmental Sensitivity And Responsibility: An Indicative Analysis On Billboards
}

\begin{abstract}
The ecological destruction of the planet that has become a globalized and human-centered, has been addressed by many disciplines. The anthropocene, which came to the agenda with the deterioration of the ecological balance, is a concept that deals with the destruction of humans on the world. The use of fossil fuels, which continues to increase with the industrial revolution, increases the greenhouse gas effect in the atmosphere and significantly affects global warming. Ecology, which requires an integrated structure, makes it compulsory for businesses to take steps in this sense. With the increasing globalization and competitive environment, companies are the subjects that will contribute to the sustainability of both the society and the planet in the macro sense by basing public relations, social responsibility, advertising, marketing and brand studies on sustainable green philosophy. The fact that businesses do not fully adopt a profit-oriented philosophy and develop environmentally responsible projects shows that they have taken a preventive step towards global environmental problems in this sense. In this context, green public relations, which serve as a bridge between the business and the consumer, constitute an important part of the communicative studies to be conducted. In this sense, a semiotic analysis was examined within the scope of the subject by including billboard projects, which are one of the public relations tools, and it was noted that the environmentalist billboard activities both contributed to sustainability and were more preferred by consumers.
\end{abstract}

Keywords: Green Public Relations, Anthropocene, Environmental Sensitivity and Responsibility, Environmental Problems, billboard 


\section{Giriş}

İnsanların da bütün canlılar gibi var olma aşamasında doğaya bağımlı olması, insan-doğa etkileşiminin temelini meydana getirmektedir. Doğanın ve çevrenin zamansal değişimlerine adapte olmak ve bu şartlarda yaşamak durumunda olan insan ve tüm canlılar bu sayede doğa ile devamlı bir ilişkide varlığını devam ettirmektedir. Bu zorunlu durum, insanın gereksinimleri ve öngörüleri noktasında kendi durumunu merkeze alma gayretiyle sürekliliğini sağlamaktadır (Sümer ve Diğerleri, 2020, s.2). Bu anlamda dünya genelinde ortaya çıkan geniş kapsamlı teknolojik gelişmeler insan hayatını etkilemekte ve dünyanın bir köy haline gelmesine sebebiyet vermektedir. Bu gelişmeler ışığında doğal kaynakların azalması, ozon tabakasının incelmesi, hızlı nüfus artışı, hava ve su kirliliği ve benzeri durumlar insanları olumsuz şekilde etkileyebilecek birtakım küresel sorunların tüketicilerce dikkate alınması, onların gelecek ve yakalamak istedikleri yaşam kalitesi ile ilgili endişelerini ortaya çkarmaktadır (Özkaya, 2010, s.256).

Bu endişelerden yola çıkarak, insanlığın dünyada ciddi ve kalıcı çevre sorunlarına sebep olduğunu ileri süren antroposen kavramı, 20. yüzyılın ilk yarısında kullanılmasına rağmen, tarihsel anlamda 2000'den sonra medya ve politika alanında benimsenmektedir. Antroposen merkezli çevre sorunlar1nın bilimsel kabulü ile kavramın toplumda kabul görmesi arasında geçen zaman, diğer çevre sorunlarında da görülen bir toplumsal inşa aşamasında yerini almaktadır (Eryılmaz, 2018, s.211). Bu inşa aşamasında ortaya çıan değişimler ve dönüşümlerin etkilerine nasıl uyum sağlayacağı ya da bu etkilerin nasıl azaltılacağı ile ilgili gündemdeki politik ve ekolojik tartışmaları; çevresel yıkımlardan ve yaşam alanlarının kaybından dolayı oluşan canlı soylarının tükenmesini, okyanustaki ölü bölgelerin genişlemesini, okyanus asitleşmesi ve küresel ısınma gibi birçok yıkıcı ekolojik değişimleri ortaya çıkaran toprak, okyanus ve atmosfer bileşiminin biyojeokimyasal başkalaşımı gibi çevre sorunlarını gündeme getirmektedir (Demos: 2017, s.8-9).

Günümüzde, çevre sorunlarıla bireysel ve toplumsal hayatta hissedilir oranda karşılaşılmaktadır. Toplumlar ve tüketici olarak bireyler, çevre sorunları sebebiyle yaşamlarını sürdürecek çevresel kaynakların git gide azaldığını fark etmektedir. Bunun neticesinde çevreye ilişkin sorumluluklarının bilincinde olan tüketiciler ortaya çıkmaktadır (Kükrer, 2012, s.4506). Tüketicilerin 
bu kaygılarının ortadan kaldırılması için işletmelerin sosyal sorumluluk anlayışı çerçevesinde üretim faaliyet ve uygulamaların daha çevreci hale dönüştürmeleri bir gereklilik haline gelmektedir. $\mathrm{Bu}$ anlamda işletme yöneticilerinin ekolojik çevreye yönelik değişim şeklindeki bakışlarını hızlı bir şekilde ortaya koymaları ve planlanan faaliyetlerle ilişkili kararlar verirken ekolojik çevreyi, kararları etkileyen önemli bir etmen olarak görmeleri dünyanın gelecek şekillenmesi açısından oldukça önemlidir (Özkaya, 2010, s.256).

Çalışmada antroposen kavramı bağlamında dünyanın çevre sorunlarına duyarlı işletmelerin sorumlulukları ele alınacak ve halkla ilişkiler araçlarından billboardların yeşile katkı sağlamak açısından nasıl değerlendirildiğine bakılacaktır. Halkla ilişkiler aracı olarak kullanılan billboardlar yeşil çevre anlamında ne içermektedir, çevreye nasıl katkı sunmaktadır, nasıl mesaj vermektedir bu sorulara göstergebilim analizi yapılarak cevap aranacaktır.

\section{Antroposen Kavramı}

İnsanlık tarihi boyunca devam eden doğa-insan etkileşiminin sanayi devrimine kadar doğanın lehine olduğunu söylemek mümkündür. Sanayi devrimiyle birlikte makineleşmenin de devreye girmesiyle beraber enerji ihtiyacı ortaya çıkmış ve enerji üretimi için doğal kaynakların kullanılmasını hem de aşırı oranda kullanılmasını beraberinde getirmiştir. Sanayileşmeyle birlikte dünyaya insanın etkisinin süregelen yönünün oldukça büyük olduğu bu dönem antroposen (insan çağı) olarak adlandırılmaktadır. Sanayi devrimine kadar dünyanın etkisinde kalan insanın dünyayı etkileme süreci olarak ele alınabilecek antroposen, dünyada ciddi değişimler ve döndürülemez durumların ortaya çıtığ 1 bir dönemdir. Bu dönemde iklim değişikliğinden tutun da çevre kirliliğine kadar insan eliyle hayati yaşam alanları yok edilmeyle karşı karşıyadır.

Doğadaki dengenin insan lehine bozulmuş olması ile bir kısım çevre sorunları ile karşı karşıya gelinmektedir. Bu durum her ne kadar doğayı korumaya ilişkin kitlesel insan hareketleri ile engellenmeye çalışılsa da, alınmaya çalışılan bütün tedbirler insanlığın kendi varoluşunu devam ettirmesi temelinde önem taşımaktadır (Sümer ve Diğerleri, 2020, s.2).

İnsanın doğanın bir parçası olduğunu unutmasından, kendini yine merkeze alarak önemseme hatasından ve/veya doğadaki yerini kavrayamamasindan türetilmiş (Sümer ve Diğerleri, 2020, s.2) olan ve "anthropo" kökü "- 
cene" kökü ile birleşerek Antik Yunan'da da 'İnsan Çağı' anlamına gelen Antroposen, insan eliyle doğadaki tahribatın, yeryüzünde geri dönüşü olmayan derin izler bıraktığı ve bilim insanları tarafından da bir jeolojik çağdan bir diğer çağa geçildiğini vurgulayan yeni bir kavramdır (Ünal, 2019, s.187).

Global ölçekli dünya ve atmosfer üzerinde devam eden ve önemli insan faaliyetlerinin etkileri düşünüldüğünde, jeolojide ve ekolojide insanlığın merkezi rolünü vurgulamak için antroposen terimini kullanmanın daha uygun olduğu görülür. Şu an ortaya konulan insan aktivitelerinin etkileri uzun dönemlerde de devam edecektir (Crutzen and Stoermer, 2000, s.17). Ve bu etki Antroposen Plantationocene, ve Kapitolosenin konularının adlandırması, ölçek, oran/hız, senkronize ve karmaşıklıkla ilişkilendirilmektedir (Haraway, 2015, s.159).

Dünya sistemi üzerinde bir bütün olarak insan faaliyetlerinin etkisinden doğan, dünya tarihindeki çok yakın kopuşu anlamak için antroposen kavramının anlaşılması ve insanlığın ne ile yüzleşeceği, bu kavramı sağlam bir şekilde anlamaya ve dünya sistemi biliminin yeni disiplinlerinden doğmasına bağlıdır (Hamilton, 2016).

Örneğin iklim değişikliği, ozon tabakası ve asit yağmurları benzeri küresel boyutta etkin olan insan kaynaklı çevre sorunları ile bunlara ilişkin somut çözümlerin son zamanlarda uygulamaya geçmiş olması, antroposen etkilerinin çözümüne yönelik tekliflerinin uygulanmasını kolay hale getirmekte ve bütün çevre koruma gayretlerini antroposen şemsiyesi altında toplamayı mümkün kılmaktadır. Avrupa Birliği ve Birleşmiş Milletler benzeri uluslararası ölçekteki siyasi ve ekonomi işbirliği kuruluşlarının çevre sorunlarına ilişkin çözümlerini antroposen kavramına dayandırması (Eryılmaz, 2018, s.231232) sorunlara tüm dünyanın dikkat kesilmesi için önemli bir göstergedir.

\section{Çevre Sorunları}

Çevre kavramı; hava, su, toprak, doğa gibi yeşili sembolize eden kavramları içine almaktadır. Bu kavramların sistematiğinin bozulması, insan eliyle tahribata uğraması ve kendini toparlamaması çevre sorunu olarak görülmektedir.

Doğal yaşam sahalarının tahribatı, biyolojik çeşitliliğin azalması, elverişli tarım havzalarının tükenmeye başlaması, tatlı su oranının artan talebe cevap 
veremeyecek hale gelmesi, havaya ve suya karışan zehirli kimyasal oranındaki artış, sera gazı emisyonunun küresel ısınmaya sebebiyet vermesi ve buzulların erimesine neden olması dolayısıyla denizleri yükseltmesi temel çevre sorunları olarak sıralanmaktadır (Korten,2005 akt.Tellan, 2015, s.78).

Çevre sorunları son zamanların en önemli sorunlarındandır. Uygulamalarıyla, üretim aşamalarıyla, ürünleriyle ve çevreye bıraktıkları atıklarla, çevre sorunlarının en önemli kaynağı olarak kabul gören işletmelerin (Ayyıldız ve Genç, 2008, s.520) çevresel duyarlılık ve sorumluluk açısından sadece kar odaklı düşünmeyerek çevreye yönelik yapacağı çalışmalar da önemli hale gelmektedir.

Geniş bir topluluğun üyesi olduklarının ve bu nedenle çevre açısından sorumlu bir şekilde davranmaları gerektiğini anlamaya başlayan işletmelerin, kar odaklı amaçları kadar çevreye yönelik amaçlarını da başarmaları önemlidir. Çevresel konuların işletme kültürüyle bütünleşmesiyle neticelenecek bu durumda işletmeler, çevreye karşı sorumlu olmayı bir pazarlama aracı olarak değerlendirmek ve bunu göz önüne koymadan ve kullanmadan çevreye karşı sorumlu olmak şeklinde iki bakış açısına sahiptirler (Aytekin, 2007, s.4).

\section{Çevresel Duyarlılık ve Sorumluluk}

Antroposen çağında çevreci anlayışın ve iyimser ekosisteme destek organizasyonlarının, erdemli birer insan olarak 'gezegenin geleceğine nasıl hizmet ederiz?' sorusuna aradığı cevap, bununla birlikte çağın olumsuzluklarına yönelik birer savunma olarak ortaya çıkmaktadır (Ünal, 2019, s.189). Aynı şekilde bu soruyu işletmelerin kendilerine sorması ve çevreye duyarlılık ve sorumluluk açısından çevre yönetimini benimsemeleri çevreci anlayışların öne çıkması adına önem taşımaktadır.

$\mathrm{Bu}$ anlamda çevre yönetimi, yalnızca bir kontrol sistemi değil; işletmenin çevre hususundaki sorumluluklarına yanıt verici ve bununla birlikte riskleri azaltıcı, pazar imkânlarını arttırıcı fonksiyonlara sahiptir. Çevre yönetimi, işletmenin çalışmalarından ortaya çıkan ekolojik çevre üzerindeki etkilerini en aza indirme ve çevrenin işletme üzerindeki etkilerini organize etmektedir (Özkaya, 2010, s.250).

Dolayısıyla, işletmelerin üretim aşamalarını daha az çevresel atığa sebep olacak biçimde yeniden tasarlamaları, ürünleri çevreye etkilerini minimum düzeye indirgeyecek biçimde dizayn etmeleri, geri dönüşüm aşamalarıyla 
çevresel atıkları minimize etmeleri ve çevredeki atıkları da en az çevresel zarara neden olabilecek biçimde dönüştürmeleri, ambalaj ürünlerini çevreye zararı az olan ve toprakta ayrışabilen maddelerden tercih etmeleri ve ambalaj oranını mümkün olduğunca azaltmaları çevre sorunlarının azaltılması bakımından önem taşımaktadır (Ayyıldız ve Genç, 2008, s.520).

Çevreye duyarlı ve sorumlu olmak bir işletmeye halkla ilişkiler ve imaj açısından da önemli avantajlar getirecektir. İşletme piyasada toplumsal sorumlu kabul görecek ve çevre bilincine sahip duyarlı bir işletme olarak öne çıacaktır. Bundan başka işletmelerin kendilerine özgü ve diğer işletmeler tarafından taklit edilmesi zor çeşitli çevre stratejileri belirlemeleri, onların sektör bazında lider durumuna gelmelerinde oldukça etkili olacaktır. Çevreye sürdürülebilir kalkınma boyutuyla bakmak, günümüzde işletmelere rekabet avantajı sağlayacaktır (Aytekin, 2007, s.5).

Sosyo-ekonomik bir varlık olduğu düşünüldüğünde işletmeler, tüketicilerin davranışlarını yönlendirebilen çevre duyarlılığı noktasında tepkisiz kalamazlar. Yalnızca kar elde etmeye çalışan işletmeler olarak değerlendiren eski anlayış, sosyal sorunlara duyarlı, kaliteyi amaçlayan işletmeler olarak değerlendiren yeni bir anlayışa yerini bırakmaktadır. Bu yeni anlayış kapsamında çevre dostu ürünler sunmanın ve pazarlar tercih etmeninin yanında temel olarak çevre dostu yaklaşımının kurum kültürüne iyice yerleşmesi önemlidir (Erbaşlar, 2012, s.95).

Bu anlamda işletmeler çevresel duyarlılık hususunda tüketici istek ve beklentilerinin karşılanmasında daha hassas olmalıdırlar. Unutulmamalıdır ki gelecek nesillere yaşanılabilir bir dünya bırakmak isteniyorsa tüketiciler yeşil ürünler hususunda bilinçlendirilmeli, yeşil ürün fiyat anlamında dezavantaj olmaktan kurtarılmalı ve yeşili merkez alan çalışmalara her zaman olduğundan çok daha fazla önem verilmelidir (Çetin ve Korucuk, 2018, s.88). Bu çalışmalar yeşilin öne çıkarıldığı ve tüketici nezdinde kabul görebilecek bir takım tasarımlarla ortaya konulmuş kavramları içermektedir. Yeşil markalama, yeşil tüketimcilik, yeşil pazarlama, yeşil reklam kavramları bu anlamda ele alınabilecek kavramlardan bazılarıdır.

Yeşil Markalama: Markaların çevreye duyarlı olmalarının ve sosyal çevreyle ilişkili sosyal sorumluluk projeleri ortaya koymanın tüketiciler açısından önemli olduğu; çevre itibarının ve algılanan kaliteli yeşil markalamanın tüketicilerin kararları ve satın alma tercihleri noktasında oldukça etkili olduğu 
ifade edilmektedir. Çevreye duyarlı ve algılanan yeşil kalitesi yüksek markalar, diğer markalar ile kıyaslandığında daha önde görünmektedir (Tarakçı ve Göktaş, 2019, s.1106).

Yeşil markalamanın kurum stratejisi olarak tercih edilmesi, ürün bilinirliğinde, tercihinde ve sürdürülebilirliğinde şirketlere kazanımlar sağlamaktadır. Yeşil markalama yoluyla işletmelere sunulan ekolojik tercihler; hukuk, hesap verilebilirlik ve etik açısından esnek yollar sunmaktadır (Tellan, 2015, s.85). Dolayısıyla, markalar değerlerini yeşil marka olarak devam ettirmelidirler. (Tarakçı ve Göktaş, 2019: 1106). Bu şartlar altında, ürünlerin ambalajlarında çevre için güvenli, çevre dostu, geri dönüşümlü, ozon tabakasının dostu ve 'eko-güvenli' benzeri unsurların bulunması gerekli olmaktadır (Tellan, 2015, s.82).

Yeşil Tüketim: Yeni davranış olarak yeşil tüketim hususunda tüketiciler, vicdani olarak kendilerini rahatlatma ve kendi iç çatışmasından kaçınmak amacıyla çevre dostu olabilecek veya çevreye zarar vermeyecek organik ürünleri tercih etme eğilimi göstermektedirler (Tellan, 2015, s.82). Artık uluslararası işletmelerin, yüksek bir oranda ürün ve üretim süreçlerinde çevreci düşünceleri tercih etmektedir. Bu düşüncelerin ortaya çıkardığı en etkili teori; ürün ve üretim aşamalarının sürdürülebilir ve çevre dostu olmasıdır (Turan, 2014, s.2).

Çevre dostu ürünleri, ambalajlamayı ve yönetim tarzlarını isteyen yeşil tüketiciler; bilinçli bir yaklaşımla çevreye bakan, layık olduğu önemi gösteren işletmeleri tercih etmektedirler. Böylelikle işletmeleri, çevreye duyarlı tüketicilerin taleplerine yönelik ürünler üretmeye, onların istedikleri biçimde ambalajlamaya ve çevre dostu uygulamalara yöneltmektedir (Aytekin, 2007, s.5). Dolayısıyla, çevreyi koruma ya da çevreye daha az zarar verme noktasinda yapılabileceklerden biri olarak yeşil tüketim (green consumer) tavsiye edilmekte ve yaygınlaştırılması desteklenmektedir (Turan, 2014, s.2).

Yeşil tüketim yaklaşımında kaynakların sürdürülebilirliğini devam ettirebilmek amacıyla 3-R öne çıkmaktadır. Azaltmak (reducing), yeniden kullanmak (reusing) ve geri dönüşüm (recycling) olarak kaynakların bir yaşam döngüsünde hareket ettiği öngörülen bu anlayışta, çocukluk döneminden yola çıkarak tüketicilerin tamamına benimsetilmesi kaçınılmaz bir gereklilik (Özkaya, 2010, s.250) olarak ortaya konulmaktadır. 
Yeşil Reklam: Günümüzde toplumun tamamını büyük ölçüde etkileyen ve çözülmesine ihtiyaç duyulan bir sorun haline gelen doğal çevrenin korunabilmesi önemlidir. Tüketicilerin çevresel değerlerin geleceğiyle ilişkili endişeleri gün geçtikçe artmasına rağmen, satın alma, tüketim ve ürün geri dönüşüm aşamalarında çevresel değerlere yeterince önem vermedikleri görülmektedir (Çetin ve Korucuk, 2018, s.88).

Üretim yapan şirketler ile ürünleri satın alan gerçek ve muhtemel müşterilerin, işletmelerin ürünlerini tercih etmesi yönündeki iletişim ve pazarlama aracı olan (Fidan, 2007, s.108) reklamlar, ürün tanıtımında işletmelerin en çok tercih ettikleri yöntemlerdendir. Yeşil reklamlar tüketicilere ekolojik bilinci kazandırır ve yeşil bir yaşam biçimini destekletir. Ayrıca tüketiciyi, üretimi yeşil hassasiyetiyle yapan işletmelerin ürünlerini tercih etmesi ve satın alması hususunda yönlendirir (Aydoğan ve Dinar, 2019, s.245).

Yeşil reklam, malların veya hizmetlerin doğaya zarar vermeyecek biçimde üretileceğini, fiyatlarının uygun tutulacağını, buna ek olarak istek ve ihtiyaçları hususunda gerçek ve muhtemel müşterilerin tatmin edebileceğini, müşterilere tanıtmak ya da şirketin sosyal sorumluluğu bakımından çevreye duyarlı imajı ortaya koyabilmek amaciyla yapılan reklam (Kuzucu, 2018, s.25) biçiminde tanımlanabilir. Reklam rekabeti getirmektedir.

Rekabeti avantaj olarak değerlendirmek isteyen şirketler rakiplerinden her daim önde yer almaktadır. Bu anlamda şirketler, gelişen rekabet şartlarını önemsemeli, çevreyi dikkate almalı ve çevresel hususları her daim işletmeyle bir arada değerlendirerek faaliyetlerini sürdürmelidir (Aytekin, 2007, s.5-6). İşletmeler, bu hususları reklamlarında öne çıkararak tüketici isteklerinin çevreye zarar vermeyen ürünlerine yönelmesini, içinde bulundukları pazar paylarını artırmayı, rakiplerine karşı bu alanda üstünlük sağlamayı amaçlamaktadır (Erbaşlar, 2012, s.97).

Yeşil Pazarlama: Çevresel duyarlılık, rekabet içinde bulunulan durumda işletmeler için bir farklılık ortaya koyma ve rekabetçi üstünlük belirlemede önemli bir adım olarak değerlendirilmelidir. Yeşil pazarlama kavramının ortaya çıkışı ve önemli hale gelmesi bu hususta ön plana çıkmaktadır (Tayfun ve Öçlü, 2015, s.96).

Toplumun taleplerini ve beklentilerini tatmin etmek üzere birtakım değişimlerin ortaya konulması ve kolayca uygulanması maksadıyla çevreye en az zarar vermek düşüncesiyle uygulanan çalışmalar (Erbaşlar, 2012, s.96) olan 
yeşil pazarlama, pazarlama faaliyetlerinde çevresel durumları dikkate almayı, bu hususlara karşı hassasiyet göstermeyi, doğal kaynakların fazla tercih edilmesinin önüne geçmek maksadı taşıyan ve bütün pazarlama kararlarında toplumsal yararı amaçlayan bir anlayış geliştirmeyi (Koçoğlu ve Koçoğlu, 2017, s.418) ele almaktadır.

İşletmelerin önemli bir toplumsal sorumluluğu olan yeşil pazarlama, çevrenin temiz tutulmasının, korunması ve çevreye duyarlı ürünlerin üretilmesi ve tüketilmesini içermektedir. Çevresel hususlarda işletmelerde olduğu kadar tüketiciler de sorumluluk bulunmaktadır (Koçoğlu ve Koçoğlu, 2017, s.418).

Çevrenin korunması hususunda tüketicilerin gittikçe daha fazla bilinçli hale gelmesi önemlidir. İşletmeler bakımından yeşil pazarlama uygulamaları maliyetlerin aşağıya çekilmesini, satışların yükselmesini sağlarken daha az girdiyle daha az atık meydana geleceğinden, kaynak tercihinde verimlilik ve finansal tasarrufa ve kazanca sebebiyet verecektir (Erbaşlar, 2012, s.101).

Tüketicilerin çevreye karşı duyarlılığı, içinde bulunulan sektördeki rekabet gücü ve çevreci yasaların uygulanabilirliği, işletmelerin çevreciliğe yönelik duyarlılığı ile bir araya gelerek yeşil pazarlama aracilığıyla en üst düzey işletme performanslarına yansımaktadır. Bu performanslar arasında bir köprü vazifesi üstlenerek sürecin tamamlanmasına destek olan (Ayyıldız ve Genç, 2008, s.507-508) yeşil pazarlamanın tercih edilmesinin önemli sebeplerinden birisi de işletmelerin var olan pazardaki rekabetçi durumlarını kaybetmek istememeleridir. Bu sebeple işletmeler çevreye zararlı olabilecek ürünler üretmeyerek yerine çevreye ve doğal hayata zararlı olmayan ürünleri üretim sürecine dahil etmeye başlamaktadır (Erbaşlar, 2012, s.97).

\section{Yeşil/Çevresel Halkla İlişkiler}

Günümüzde işletmelerin etkinlik içinde oldukları çevrelerinde çok hızlı ve devamlı bir şekilde ekonomik, sosyal gelişmeler ve değişiklikler görünmektedir. Çevrelerinde ortaya çıkan bu farklılıklar karşısında işletmelerin ayakta durmaları ve varlıklarını devam ettirebilmeleri için başarılı ve etkili bir biçimde yönetilmeleri (Özdönmez ve Ark., 1999, s.9) önem taşımaktadır.

Halkla ilişkiler, işletme ve çevresi arasında ilişkileri düzenlemek ve yürütmek, işletmeyi hedef kitleye anlatmak ve imaja yönelik faaliyetler yapmak, 
hedef kitleyi ikna çalışmaları sunmak, hedef kitleye ilişkin ilgi ve dikkati çekmek özeliğine sahiptir (Akdağ, 2010, s.83). Dolayısıyla, halkla ilişkiler etkileşim kuran bir sistem olduğundan, etkin ve doğru bir iletişime ihtiyaç duymaktadır. İşletme ve çevresi arasında planlı ve düzenli bir iletişim ortaya konulabilirse, halkla ilişkilerin başarı düzeyi yükselecektir (Gürüz, 1993, s.22). Bu çalışmada yer alan antroposen kavramı insanlığın çevreye verdiği zarardan yola çıkmaktadır. Aslında işletmelerde yer alan halkla ilişkiler ise hem tüketicilere hem de topluma karşı işletmelerin sorumlu olduğunun bir göstergesidir. Halkla ilişkiler yaptığı çalışmalar ile işletmelere katkı sunmasının yanı sıra topluma olan sorumluluklarının yerine getirmesine de destek olmaktadır. Çevre, toplum için önemli olduğundan evrenin işletmeler tarafından kirletilmesi de toplumun tepkisini çeken bir durum olarak görülmektedir. Antroposen çağında bu durum biraz daha önem kazanmaktadır. İşletmelerin çevreye karşı sorumlulukları daha fazla öne çımaktadır.

Çevrenin korunması başarısı, toplumsal sorumluluk hususlarında mümkün olduğunca geniş bir hedef kitleye ulaşılabilmesi için etkinliklerinin planlanması ve uygulanması aşamasında halkla ilişkilere ihtiyaç duyulmaktadır (Şeşen, 2015, s.430). Halkla ilişkiler, bir yönetim fonksiyonu olarak işletmelerin tüm kademelerinde iletişim 'planlayıcısı' ve 'uygulayıcısı' rolünü üstlenmektedir. Çevre sorunları ortaya çıktığında devreye giren halkla ilişkiler, planlayıcı ve uygulayı r rolü gereğince geliştirdiği çözümlerle işletmenin kendini yenileyerek devamlılığını sağlamak (Tellan, 2015, s.86) açısından önemlidir.

İşletmelerin kar amaçlı faaliyetlerin yanında kardan ödün vererek veya daha az kar ile toplum yararına ortaya koydukları ve birlikte yaşadıkları çevreye karşı sorumluluk hissetmeleri toplumsal sorumluluk olarak değerlendirmektedir. İşletmelerin topluma karşı yapabileceklerinin ve artan sorumluluğunun her zaman olacağının ve toplum için de var olduğunun (Akdağ, 2007, s.207-208) halkla ilişkiler tarafından sürekli vurgulanması önemlidir.

İşletmelerin kendi yararlarından başka toplumun varlığın kabul etmesi, asıl işlerinin dişında toplumsal sorunlara da duyarlı olması, izlenecek yollarla varılacak sonuçları öngörebilmesi, sorumlu davranışın ve iyi bir kurumsal vatandaş olabilmenin temelini oluşturmaktadır (Peltekoğlu, 2018, s.198-199). Toplum, işletmeyi çevre konusunda yanında görmek istemektedir. Ürün sunarken yapılan çalışmalar bile bu anlamda toplumun dikkatini çekmektedir. 
Çevreye zarar verici unsurlardan kaçınan ve iyi bir kurumsal vatandaşlık örneği sergileyen işletmeler diğer işletmelere nazaran daha ön plana çımaktadir.

Çevrenin, tüketim odaklı bir kârlılık ve çalışmalar sayesinde tahrip edilmesi, üzerinde önemle durulması ve acil çözümler ortaya konulması gereken bir husustur. Çevre sorunlarının çözüme kavuşturulması, etik değerlere, sosyal sorumluluklara ve insan hayatına sahip çkan işletmelerin pazarda güç kazanması ve bu işletmelerin tüketicilerinin uzun vadeli çıkarlarını kısa dönemli kâr düşüncelerine tercih etmelerinde mümkündür (Tellan, 2015, s.79).

$\mathrm{Bu}$ durumda işletmelerde halkla ilişkilere büyük görevler düşmektedir. Halkla ilişkiler işletmeleri toplumun yararı hususunda bilinçlendirmeli ve yapılan çalışmalarda yeşilin öne çıkmasına ve toplumun zarar görmemesine odaklanmalıdır. Antroposen çağı insanlığın eliyle dünyanın kirletildiği bir çağdır. Bu olumsuz durumda çıkıs, yine çevre konusunda duyarlı ve sorumlu işletmeler ve bünyelerinde bu konuda hassasiyet gösteren halkla ilişkiler tarafından yeşilin ve çevrenin korunması üzerine yapılacak çalışmalarla mümkün olacaktır.

Bu çalışmalar, daha yeşil bir çevre, doğal kaynaklara saygi, gezegeni kurtarma gayret ve yaklaşımlarıyla ağırlık kazanmaktadır. Kentte betonlaşma veya cam kafesten gökdelenlerin yerine yeşil binaların tasarlanması, alışveriş merkezlerinin çevresine düşünülen yeşillikler ve yapay bahçeler bu anlamda çevre duyarlılığı (Ünal, 2019, s.189) ve sorumluluğu neticesinde ön plana ç1kan durumlardır. Yeşil çevre hususunda yasal düzenlemeler ve anlaşmalar ile birtakım tedbirle sonucunda kloroflorokarbon (CFC) gazı kullanımının azaltılması sağlanabilmektedir (Tellan, 2015, s.81).

Örneğin, çevre ile uyumlu teknolojiler tercih ettiğini Exxon Mobil, çevreye zararı olmayan plastik şişeler kullandığını The Body Shop belirtmektedir. HP ise yeniden kullanılabilirlik ve geri dönüşüm sahasında ilk faaliyeti olan işletmelerden biridir (Turan, 2014, s.2).

Starbucks, çevreye bıraktığı karbon ayak izini aza indirmek ve iklim değişikliği ile mücadele edebilmek için çalışmalarını devam ettirirken, içinde yer aldığı toplumlara katkı sunmak amacı ile birtakım projeler yürüttüklerini belirtmektedir. İklim değişikliğine karşı kahve üretilen bölgelerdeki ormanları korumak ve üretim sürecindeki çiftçilerin hayat standartlarını yükseltmek amacıyla birçok çalışmayı ortaya koymaktadır. Starbucks'ın enerji ve su ta- 
sarrufuna azami dikkat ederek; plastik bardaklarla ilgili atıkların aza indirilmesi, geri dönüşümünün artırılması, çevreci tasarımının desteklendiği mağaza sayılarının artırılması ve çevreye bıraktıkları ayak izlerini önemli boyutta küçültmek için çalışması (www.starbucks.com.tr) sosyal sorumluluk yaklaşımı boyutunda değerlendirilebilir.

Yine örneklendirmek gerekirse Vestel, Bosch benzeri birçok işletme çevreye daha az zarar verecek beyaz eşya üretmekte olduklarını reklamlarında sürekli ifade etmektedir. Timberland ve Camper gibi markalar ayakkabılarında geri dönüşebilir malzemeler tercih ederek çevreyi korumaya çalıştıklarını ifade etmektedir. Levis, Zara, GAP, Nike gibi uluslararası işletmeler ise koleksiyonlarını organik, ekolojik ürünlerle zenginleştirmeye çalışmaktadır (Turan, 2014, s.2).

Çevreci faaliyetlere söylemlerinde ve eylemlerinde yer vermek kurumsal işletmelere büyük bir itibar kazandırmaktadır. Son dönemde yapılan çalışmalara bakıldığında birçok çevreci faaliyet içerisinde en çok dikkat çeken ve bu çalışma içinde ele alınan, yeşil billboard projeleridir. Özellikle sanayileşmenin yoğun olduğu ülkelerde hava kirliliğini önlemek ve doğanın sürdürülebilirliğini sağlamak amacıyla bu tür projelere imza atıldığı gözlemlenmektedir. Bu bağlamda yeşil çevre ile ilişkili sorunları sürdürülebilir çözümler getiren önemli projeler arasında yer almakla birlikte yapılacak çalışmalara da önemli bir örnek teşkil etmektedir.

\section{Çevresel Duyarlılık ve Sorumluluk Açısından Yeşil Billboardların Göstergebilim Analizi}

Doğal kaynakların bilinçsizce kullanılması dolayısıyla tükenme noktasına gelmesi, iklim değişikliklerinin hızlı bir şekilde seyretmesi ve doğal afetler gibi sorunlar hemen hemen bütün markalar üzerinde bir baskı unsuru haline gelmektedir. Çevre kirliliği noktasında çevresel duyarlılık ve sorumluluk, işletmelerin yeşile yönelik ürünlere önem vermeleri zorunluluğunu beraberinde getirmektedir. Bu doğrultuda, işletmelerin çevresel duyarlılık ve sorumluluk olarak yeşilin bir parçası olması, markaların müşteri özelinde itibarını artırıcı bir unsur olarak değerlendirmektedir.

Avusturalya'da yapılan bir araştırma, tüketicilerin \%52'sinin yeşil ürünlere önem verdiğini ve yeşil reklamların da bu anlamda öne çkarılması gerektiğini ortaya koymaktadır. Yine bahsedilen çalışmanın sonuçları arasında, 
yeşile dönük olarak yapılan çalışmaların müşterilerin yeşil ürün bilgisini ve tercihlerini arttırdığı ve yeşil markaların yeşil olmayan markalara göre zihinlerde daha olumlu bir şekilde kodlandığı belirtilmektedir (Rumman ve Valenzuela, 2016, s.176-177). Shimp'e göre radyo, televizyon, internet, billbord ve diğer iletişim araçları ve göstergeleri üretim yapan işletmelerin tüketiciyle doğrudan ya da dolaylı olarak iletişim kurmasını sağlamaktadır. Müşterilere bilgi vermesi, onları ikna etmesi ve hatırlatıcı olması gibi etkileriyle ortaya konulan çalışmalar, ürünlerin tutundurulmasında önemli bir rol oynamaktadir (akt. Rumman ve Valenzuela, 2016, s.176-177).

Günümüzde çevre kirliliğinin önemli bir unsuru olan hava kirliliğinin ölümcül boyutlara ulaştı̆̆ ve insanların yer yer maskeyle dolaşmak zorunda olduğu şehirlerde işletmelerin işlevsel yeşil halkla ilişkiler kampanyaları yürütmeleri zorunlu hale gelmektedir. Daha çevreci, toplumu düşünen ve çevresel duyarlılık bilinciyle hareket eden işletmeler diğer işletmelere nazaran daha çok ön plana çıkmaktadır. Toplumsal sorumluluk bağlamında işletmelerin çevreye yönelik hassasiyetleri de bu bağlamda tüketiciler takibinde olan bir durumdur.

$\mathrm{Bu}$ anlamda daha somut ve gözle görülebilen kampanyaların yapılması, özellikle yeşil pazarlamaya ve reklamlara güvenemeyen potansiyel müşterilerin yeşil halkla ilişkiler çalışmalarıyla kazanılması önemli rol oynamaktadır. Tüketicilere yönelik yapılan kampanyalarda kullanılan ve işletmelerin mesajlarını hedef kitlelerine ulaştırmak için tercih ettikleri bir halkla ilişkiler aracı olan billboardlar slogan ya da görselleri içeren boyutları büyük ve dış mekânda tercih edilen reklam panolarıdır.

Çalışmamızda işletmelerin çevreye duyarlılık ve sorumluluk bağlamında kullandıkları ve hedef kitleye yönelik çevreci mesajları içeren billboardlar incelenecektir. Bu noktadan hareketle göstergebilimsel analiz ile ele alınacak çevreci billboard örneklerinin, konu dahilinde yapılacak çalışmalara bir temsil oluşturması hedeflenmektedir.

Göstergebilim, dil, imge ve nesneler aracılı̆̆ ile temsilin nasıl üretildiği ve anlamlandırıldığını ortaya koymayı hedefleyen bir bilim dalıdır (Curtin, 2009, s.51). Metnin arkasındaki yan anlamı ortaya çıkarmayı amaçlayan göstergebilim, gösteren ve gösterilen ilişkisinden oluşmaktadır. Göstergenin iki yönünü temsil eden gösteren, duyu organlarımız aracılığı ile algılayışlarımıza karşılık gelirken, gösterilen ise zihnimizde oluşan imajları temsil etmektedir. Yapısalcı dilbilimine göre dış dünya, bütünlüklü bir yapıya sahiptir. Bu 
bütünlüklü yapının insan zihninde canlandırılabilmesi için sınıflandırılmaya ihtiyaç vardır. Bu sebeple göstergebilim, dil aracllı̆̆ ile bütünlüğü parçalara bölerek algılamayı kolay bir hale dönüştürme işlevi görür (Moran, 2002, s.189-190). Görünenin ardındaki ikincil anlamı ortaya çkarmayı hedefleyen göstergebilim, nitel araştırma yöntemi arasında yer almaktadır.

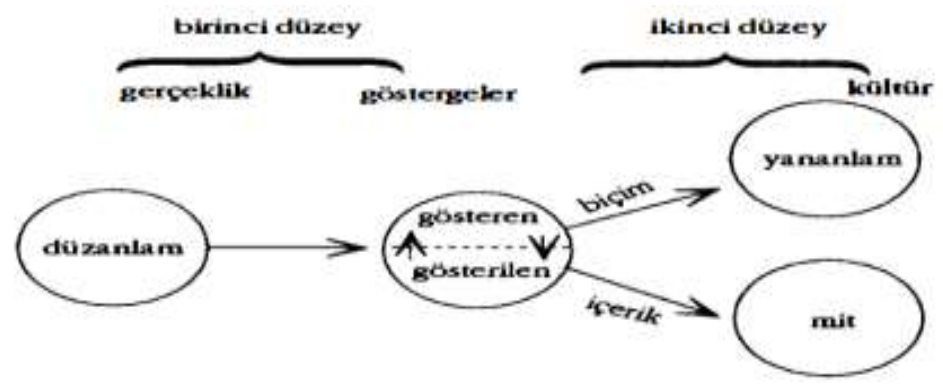

Şekil 1. Barthes'in İki Anlamlandırma Düzeyi (Fiske, 2003, s.120).

Saussure ile başlayan göstergebilim çalışmaları Peirce, Barthes, Eco ve Bathin'e kadar uzanmaktadır. İlk görsel göstergebilim kaynağının ise Barthes ve Marin'in çalışmaları olduğu söylenebilir. Barthes, bütün görsel göstergelerin sözlü dilin bir anlatıcısı olduğunu belirtirken, mesajın izleyici tarafından nasıl algılandığını da bir anlamda göstermektedir. Barthes'a göre düz anlam, açık olarak algılanabilen ve anlamlandırılabilen bir süreç iken, yan anlam görüntünün arkasında gizlenen ikincil anlamı ortaya çıkarmayı ifade etmektedir (Yücel, 2016, s.283). Bu bağlamda Barthes' ın gösterilen içerisinde yer alan düz anlam ve yan anlam kavramları, çevreci billboardları göstergebilim üzerinden açıklamada oldukça önemli bir rol oynamaktadır.

Çalışma kapsamında Pazarlamasyon.com sitesinden seçilmiş olan dört çevreci billboard örneği değerlendirilmiştir. Konu bağlamında ele alındığı gibi antroposen çağında doğa ve insan arasındaki dengeyi sağlamaya yönelik yapılan billboard çalışmaları, artarak devam eden çevre sorunlarına karşı yapıcı bir eylem niteliğinde görünmektedir. Bu sebeple seçilen billboardlar da çevrecilik ve sürdürülebilirliğe dair kullanılan renk, materyal ve hedef kitleye verilen mesaj ön plana çıkarılmaya çalışılarak markaların çevreye karşı olan duyarlılığ1 ve sorumluluğu çalışma kapsamda incelenmiştir. Bu noktadan 
yola çıkarak küreselleşme ile artan hılı tüketim ve çevrecilik konusunda çeşitli markaların yapmış olduğu dört çevreci billboard, göstergebilim açısından aşağıdaki gibi analiz edilmiştir.

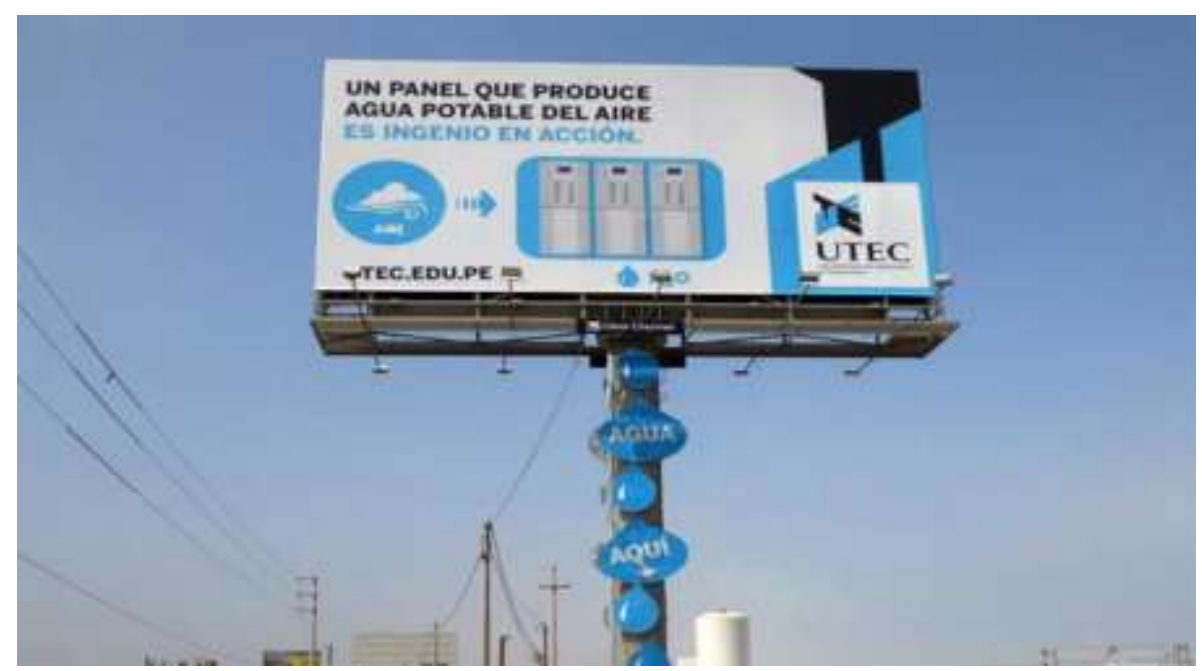

Şekil 1. Billboard: Peru Mühendislik ve Teknoloji Üniversitesi'nin Gerçekleştirdiği

Proje Billboardu (Kaynak: Pazarlamasyon)

Peru Mühendislik ve Teknoloji Üniversitesi, Peru'nun Lima şehrinde hem şehrin su ihtiyacını karşılamak hem de öğrenci sayısını artırmak için yeşil reklam kampanyası düzenleyerek temiz hava billboard projesini başlatmıştır. Bu kapsamda, çöl üzerine kurulu olan fakat \%98 oranında neme sahip olan şehirdeki nemlilik, sosyal sorumluluk çerçevesinde kullanılarak temiz içme suyu üreten billboardlara dönüştürülmüştür. Üniversitenin inşa ettiği billboardlar sayesinde 3 ay içinde 9450 litre su üretimi sağlanarak (Durgun, 2013) hem toplumun sorunlarına işlevsel çözüm getirilmiş hem de halkın gözünde oldukça olumlu bir imaja sahip olunmuştur. 
Tablo 1.Peru Mühendislik ve Teknoloji Üniversitesi'nin Gerçekleştirdiği Uygulamanın Göstergebilimsel Analizi

\begin{tabular}{|c|c|c|c|c|}
\hline Gösterge Türü & Gösterge & Gösteren & Gösterilen & Yan anlam \\
\hline \multirow{4}{*}{$\begin{array}{l}\text { Görüntüsel/Dilsel } \\
\text { (Tablo 1) }\end{array}$} & \multirow[b]{4}{*}{ Billboard } & Mavi & Gökyüzü & \multirow{4}{*}{$\begin{array}{l}\text { Temiz hava billboardları ile çevre kirli- } \\
\text { liğini önlemek ve havadaki nemi yaka- } \\
\text { layarak, temiz içme suyuna dönüşüm } \\
\text { işlemi ifade edilmiştir. }\end{array}$} \\
\hline & & Beyaz & & \\
\hline & & Bulut Damla & $\mathrm{Su}$ & \\
\hline & & Ok Makine & Dönüştürücü & \\
\hline
\end{tabular}

Peru Mühendislik ve Teknoloji Üniversitesinin yapmış olduğu billboard'un gösteren (Tablo 1) kısmında kullandığı beyaz ve mavi renkler; görsel ve bilgisel açıdan önemli veriler sunmaktadır. Gökyüzü, su ve denizin rengi olan mavi, temizlik, doğallık ve saflık imajı yaratmak amacı ile kullanmıştır. Aynı zamanda sonsuzluğun bir imgesi olan mavi, billboard'da doğanın sürdürülebilirliğinin desteklendiğine de işaret etmektedir. Bunun yanında çevreci bir türün temsili olan billboard'da kullanılan beyaz renk, istikrar, devamlılık ve temizliğe işaret ederken yine gökyüzünün bir sembolü olarak billboard'da yerini almıştır. Billboard üzerinde yine bulut, damla, ok ve makine gibi gösteren kullanımı, çalışma kapsamındaki temiz su sağlanmasına yönelik bir gösterilene işaret etmektedir.

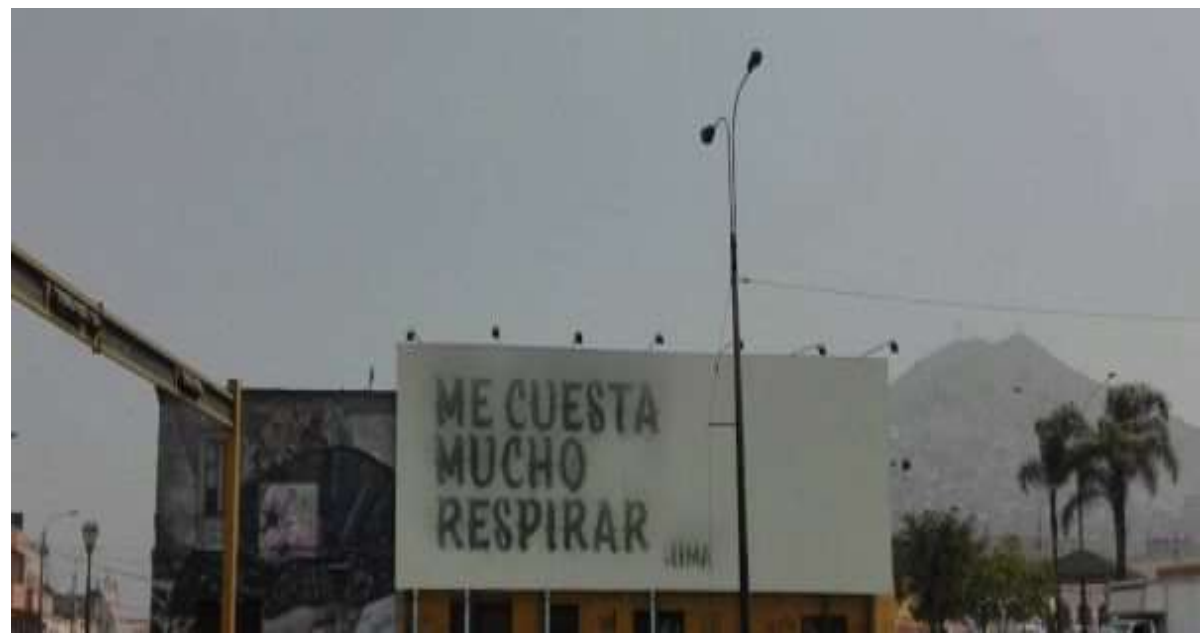

Şekil 2. Billboard: Calidda Gaz şirketi'nin Gerçekleştirdiği Proje Billboardu (Kaynak: Pazarlamasyon) 
Calidda Gaz şirketi tarafından Peru'nun başkenti Lima'da konumlandırılan temiz hava billboard'ları ise şehirdeki hava kirliliğini emen yaratıcı çalışmalar arasında yer almaktadır. "Bu bana çok fazla nefese mal oldu" sloganı ile şehrin trafiğin en yoğun yerlerinde bulunan billboard'lar, 15 gün boyunca emdiği karbondioksit ile bir mürekkebe dönüşmekte ve bahsedilen sloganı ortaya çlkarmaktadır (Pazarlamasyon.com, 2018). Bunun yanında karbondioksit seviyesinin artması ile koyulaşan mesaj, temiz havanın oluşması için beyaz alana duyulan ihtiyacı da renk metaforu üzerinden göstermiştir.

Tablo 2. Calidda Gaz şirketi'nin Gerçekleştirdiği Uygulamanın Göstergebilimsel Analizi

\begin{tabular}{lllll}
\hline Gösterge Türü & Gösterge & Gösteren & Gösterilen & Yan anlam \\
\hline & & Beyaz & Saflık, Temizlik & $\begin{array}{l}\text { Çevre kirliliğine karşı tezat } \\
\text { renkler kullanarak çevreyi ko- }\end{array}$ \\
\cline { 3 - 4 } $\begin{array}{l}\text { Görüntüsel/Dilsel } \\
\text { (Tablo 2) }\end{array}$ & Billbah & Korku, karanlık, kirlilik & $\begin{array}{l}\text { rend bana çok fazla nefese } \\
\text { rumaya yönelik bilinç uyandı- } \\
\text { rılmaktadır. }\end{array}$ \\
\hline
\end{tabular}

Calidda Gaz şirketi'nin yapmış olduğu (Tablo 2) çevreci billboard, özellikle beyaz ve siyah renk kullanarak havadaki karbondioksit kirliliğine dikkat çekmektedir. Gösterilen ilişkisi ile değerlendirildiğinde beyaz rengin bulut, gökyüzü, saflık ve temizlik gibi imgelere karşılık geldiğini söylemek mümkündür. Bunun yanında beyazın karşıtı olarak var olan siyah rengin billboard'da çevredeki yoğun hava kirliliğini temsil ettiği görülmektedir. Bu bağlamda siyah rengin gösterileni, havanın kirliliği üzerinden açıklanmaktadır.

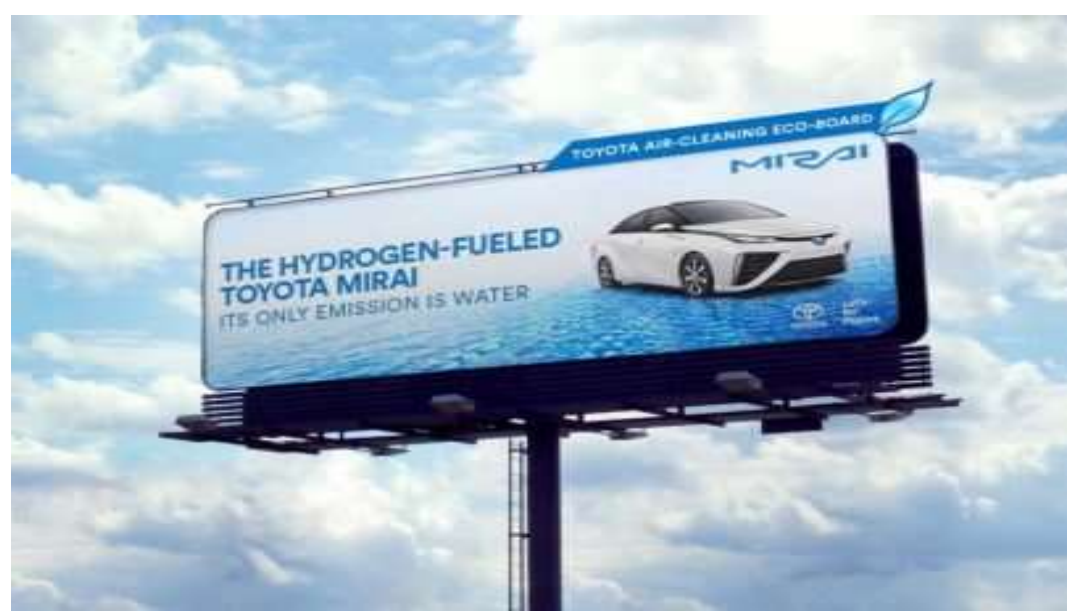

Şekil 3. Billboard: Toyota'nın Gerçekleştirdiği Proje Billboardu

(Kaynak: Pazarlamasyon). 
Toyota markası California'daki çevresel sorunlara dikkat çekmek amaciyla çevreci ürün ve faaliyetlerin yer aldığı temiz hava billboard projesi başlatmıştır. Çevreyi 2.318 metrekare bir hava temizleme yüzeyi oluşturarak koruyan billboardlar, iki ay boyunca şehrin çeşitli yerlerinde konumlandırılmıştır. Bunun yanında marka, hidrojen yakıtlı ve sadece su buharı çıaran Mirai modelinin de tanıtımını bu sayede yapmıştır (Pazarlamasyon.com, 2018).

Tablo 3._Toyota'nın Gerçekleştirdiği Uygulamanın Göstergebilimsel Analizi

\begin{tabular}{|c|c|c|c|c|}
\hline Gösterge Türü & Gösterge & Gösteren & Gösterilen & Yan anlam \\
\hline \multirow{4}{*}{$\begin{array}{l}\text { Görüntüsel/Dilsel } \\
\text { (Tablo 3) }\end{array}$} & \multirow{4}{*}{ Billboard } & $\begin{array}{l}\text { Su } \\
\text { Yaprak }\end{array}$ & Doğal Yaşam & \multirow{4}{*}{$\begin{array}{l}\text { Toyota hem kendi markasını tanıta- } \\
\text { rak çevreci olduğunu belirtmiş hem } \\
\text { de çevreyi korumak amacıyla sür- } \\
\text { dürülebilir bir yaşam için doğayı } \\
\text { desteklediğini ifade etmiştir. }\end{array}$} \\
\hline & & Araç & Çevre dostu Araç & \\
\hline & & Marka & Mirai & \\
\hline & & MaviBeyaz & Gökyüzü, Doğa, su & \\
\hline
\end{tabular}

Toyota'nın yapmış olduğu çevreci billboard (Tablo 3) örneğinde birçok farklı markanın billboard'unda kullandığı gibi ağırlıklı olarak mavi ve beyaz renklerin kullanıldığı görülmektedir. Mavi daha çok gökyüzü, saflık ve sürdürülebilirlik gibi anlamlara karşıllık gelirken, beyaz temizlik, gökyüzü ve bulut gibi imgelere karşıllk gelmektedir. Özellikle arka fonda gökyüzünün kullanılması billboard ile gerçekte olan gökyüzü arasında bir ilişki kurulduğunu göstermektedir. Çevrecilik anlamında önemli çalışmalardan birine imza atan Toyota, billboard'da kullandığı marka ile üretiminde çevre dostu araçlara yer verdiğini de bu bağlamda simgeselleştirmiştir. Dolayısıyla Toyota, çevreye zararlı olan bir araç yerine billboard'da kullandığı renkler ve semboller üzerinden çevreyi destekleyici bir araç ürettiğini göstermektedir. Yine billboard üzerinde yaprak sembolünün kullanması hem doğal yaşamın bir göstergesi hem de sürdürülebilirliğin bir imgesidir. 


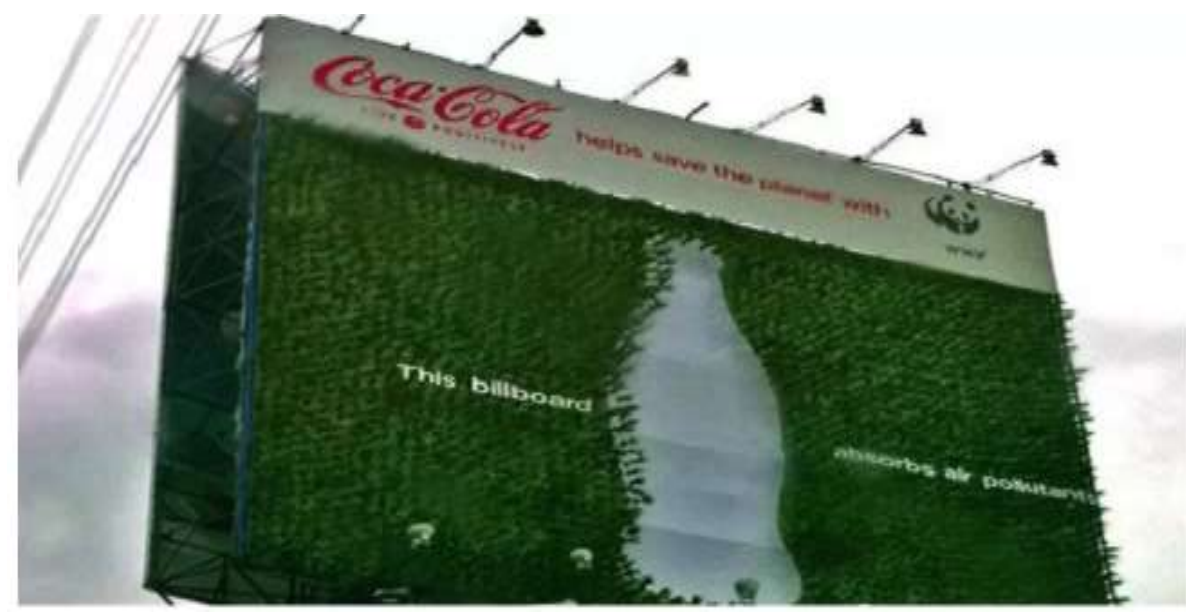

Şekil 4. Billboard: Coca Cola'nın Gerçekleştirdiği Proje Billboardu (Kaynak: Pazarlamasyon).

Filipinler'in başkenti Manila'da Coca-Cola'nın uyguladı̆̆ı yeşil billboard projesi, son dönemin en dikkat çeken yeşil pazarlama örneklerinden biridir. Tamamen geri dönüştürülebilen maddelerden imal edilen, yaklaşık 18x18 metre çapındaki billboardlar, Fukien Tea bitkisiyle kaplanarak tasarlanmıştır. Billboardlarda kullanılan Fukien Tea bitkisi Uzakdoğu'da yaygın olarak evlerde bakımı yapılan bir Bonsai ağacı türüdür. En önemli özelliğiyse yılda yaklaşık $6 \mathrm{~kg}$ karbondioksiti emebilmesi ve oksijen üretimine katkıda bulunabilmesidir. Bu bakımdan Uzakdoğu'da çok değerli olan ve hassas bir bakım gerektiren Fukien Tea bitkisi, çevre sorunlarının çözümü bağlamında ortaya konan bir proje çerçevesinde kullanılmıştır. Coca-Cola şişelerinden geri dönüşümle elde edilmiş cam çömleklerin içine oturtulan Fukien Tea bitkileri, arka planda bir sulama sistemiyle takip edilmekte ve belli bir mekanizma tarafindan

saat başı sulanmaktadır. Bu yeşil billboard projesiyle yılda yaklaşık 20 ton karbondioksit gazının emileceği belirtilmiştir. Coca-Cola, her billboardda 3.600 adet Fukien Tea bitkisi kullandığ olumsuz intibaı olumluya çevirmeyi başarabilmiştir (donanımhaber.com, 2011). 
Tablo 4._Coca Cola'nın Gerçekleştirdiği Uygulamanın Göstergebilimsel Analizi

\begin{tabular}{|c|c|c|c|c|}
\hline Gösterge Türü & Gösterge & Gösteren & Gösterilen & Yan anlam \\
\hline \multirow{4}{*}{$\begin{array}{l}\text { Görüntüsel/Dilsel } \\
\text { (Tablo 4) }\end{array}$} & \multirow{4}{*}{ Billboard } & Şişe & Coca Cola & \multirow{4}{*}{$\begin{array}{l}\text { Coca Cola, doğayı koruma vak- } \\
\text { fının markasına yer vererek, te- } \\
\text { miz hava üretimini destekledi- } \\
\text { ğine dair mesaj vermektedir. }\end{array}$} \\
\hline & & $\begin{array}{l}\text { Panda } \\
\text { Yeşil Bitki }\end{array}$ & Doğal Yaşam & \\
\hline & & WWF & Doğayı Koruma Vakfı & \\
\hline & & Marka & Coca Cola & \\
\hline
\end{tabular}

Dünyaca ünlü bir içecek markası olan Coca Cola, çevreyi koruduğuna dair yaptığı yeşil reklam çalışmaları ile son dönemde dikkat çekmektedir. Yukarıda kullanmış olduğu (Tablo 4) billboard çalışmasında Coca Cola, genel görünüm açısından yeşilin baskın olduğu bir ton tercih etmiştir. Somut olarak doğa, orman, ağaç gibi kavramları zihinlerde canlandıran yeşil rengi, daha yaşanılabilir bir dünyayı simgelemektedir. Coca Cola yapmış olduğu yeşil bitki ve panda görseli ile doğayı koruyan bir marka olduğunun da altını çizmektedir. Bunun yanında yeşilin üzerinde verilmesi gereken çevreci mesajın beyaz ile belirtmesi, çevredeki hava kirliliğinin bu çalışma ile temizlenmek istediğini işaret etmektedir. Yine billboard'da kullanılan şişe sembolü tüketicinin zihninde markayı çağrıştırmaya yönelik hazırlanmış bir gösterilen konumundadir.

\section{Tartışma ve Sonuç}

İnsanın düşünce ve yönetim biçimlerinin son derece dünyayı kontrol eder hale gelmesi, çevresel, yönetimsel ve toplumsal birçok sorunu beraberinde getirmektedir. Özellikle ekolojik alanda yaşanan çevresel tahribat, yeşilin azalarak yerini betonerme yapılara bırakmasına sebep olmaktadır. Milyarlarca yıllık bir geçmişe sahip olan gezegenimizin antroposen çağında ego merkezli bir yapıdan eko merkezli bir yapıya dönüşmesi kaçınılmaz olarak zorunludur. Bu anlamda özellikle işletmelerin küreselleşmenin de etkileri ile hem rakiplerinden farklılaşmak hem de toplumsal sorumluluklarını yerine getirmek amacıyla yeşile önem veren, doğayı koruyan faaliyetlerde bulunması günümüzde büyük bir önem arz etmektedir. Bu noktada üretim, yönetim ve karar alma mekanizmalarının koordineli bir şekilde çalışması, her geçen gün daha da önemli bir hale gelmektedir. İşletmelerin çevreci kuruluşlarla hareket etmesi, üretim ve pazarlama stratejilerini ekolojik sorunlara yö- 
neltmesi, sağlık, kalite ve güvenlik gibi sorunlara dikkat çekerek insan sağllğını tehlikeye atmaması, antroposen çağında işletmelerin yapabileceği önemli katkılar arasındadır.

Çevreye duyarlılık ve sorumluluk açısından halkla ilişkilerin de büyük bir desteğini alacak olan işletmeler, toplumun bilinçlendirilmesi ve sürdürülebilir bir yaşam desteği için yasal, ahlaki, ekonomik adımlarla tüketicinin takdirini kazanabilecektir. Bu noktada işletmeler, halkla ilişkilerin yönetim fonksiyonu ile hedef kitlenin anlayışını ve sempatisini elde ederek itibarını arttırabilmektedir. Ayrıca işletmelerin tüketici ile buluşmasında önemli bir yere sahip olan halkla ilişkiler, reklam ve pazarlama stratejilerinin yeşil odaklı olmasında ve koordinasyonun sağlanmasında önemli bir adımı oluşturmaktadır. Özellikle tüketiciye bilgi sağlanmasını, farklı ağlarla paylaşmasını kolaylaştıracak olan iletişim araçlarının doğru seçimi, çevreyi destekleyici ve canlı türlerini korumaya yönelik olan mesaj stratejileri, hedef kitlenin marka hakkındaki fikirlerini de önemli derecede etkilemektedir. Tüketicilerin satın alma davranışlarının değiştiği bu yeni çağda, işletmelerin; yeşil pazarlama, yeşil halkla ilişkiler ve yeşil reklam uygulamalarına politikalarında sıklıkla yer vererek toplumsal bir sorun olan çevresel etkilere dikkat çekmesi, işletmelerin imaj ve itibarını arttırmada kilit rol oynamaktadır. Bu anlamda çevresel sorunlara çözüm üreten işletmelerin çevre konusunda daha duyarlı ve hassas bir yaklaşım göstermeleri, toplumun menfaati için gerekli bir eylem olmakla birlikte, markanın da bu anlamda tutundurulmasında önemli bir etkiye sahiptir. Yine reklamın bilinçlendirici özelliği kullanılarak işletmelerin yeşil reklam ve pazarlama stratejileri ile potansiyel tüketicinin de bilinçlenmesini sağlayacak çalışmalar yapması, ekolojik sisteme katkı anlamında gerekli görünmektedir.

Çevresel tahribatın her geçen gün daha da artması kurumsal işletmelerin yeni medya kanallarının yanında geleneksel araçlar arasında yer alan açık hava reklamcılığını da aktif şekilde kullandığını göstermektedir. Bu anlamda incelenen Coca Cola, Toyota, Calidda Gaz şirketi ve Peru Mühendislik ve Teknoloji Üniversitesi'nin yapmış olduğu billborad çalışmaları açık hava reklamlarının en önemli ünitelerinden birisidir. Bahsedilen billboardlarda özellikle yeşile ve doğaya vurgu yapan renklerin kullanılması, sürdürülebilir bir çevre için bu anlamda ürün geliştirilmesi, halkla ilişkiler, reklam ve pazarlama stratejilerinin bu doğrultuda yeşile evirilmesi işletmelerin ekolojik sorunları ciddiye aldığını göstermektedir. Çalışma bağlamında incelenen dört 
çevreci billboard'un renk kullanımında ağırlıklı olarak sürdürülebilir bir dünya yaratmayı simgeleyen yeşil, beyaz ve mavi renklerinin kullanıldığı gözlemlenmiştir. Bunun yanında çevreyi kirleten karbondioksit, siyah rengi ile belirtilerek çevreci oluşuma önem verilmesi gerektiğini ortaya koymaktadır. Ayrıca ekolojik dengenin sağlanmasına yönelik billboard'larda kullanılan su, yaprak ve çeşitli bitkilerin marka ile bütünleştirilmesi, tüketicinin zihninde markaya karşı olumlu bir algı yaratmaktadır. Yine yapılan göstergebilimsel analizde doğayı sembolize eden gökyüzü ve bulut gösterenleri sürdürülebilirliğin bir parçası olarak ifade edilmektedir. Antroposen çağında işletmelerin pazarlama, reklam ve halkla ilişkiler çalışmalarını çevreci renk ve semboller üzerine kurması tüketicilerin zihninde sürdürülebilir bir dünya fikrini yaratmada önemli bir rol oynamaktadır.

Sosyal sorunlara öncelik vermenin önem arz ettiği günümüz dünyasında, çevreci sosyal sorumluluk projelerinin de sürdürülebilir olması önem arz etmektedir. Özellikle tüketici için yeşil ürünleri satın almanın değer kazandığ bir dönemde sektörel olarak işletmelerin kâr odaklı bir yapıdan çıkarak toplumun çıkarlarını da göz önünde bulunduracak faaliyetlerde bulunması, giderek artan çevre sorunlarına bir katkı niteliğinde önem taşımaktadır. 
EXTENDED ABSTRACT

\title{
Green Public Relations And Antropocene Concept In The Context Of Environmental Sensitivity And Responsibility: An Indicative Analysis On Billboards
}

\author{
Mustafa Akdağ, Merve Özdemir \\ Erciyes University, Cappadocia University
}

Because pollution is an international problem in many ways, it has become an important issue that needs a universal solidarity and reaction. Pollution, one of the most important question in the world, is not a problem that can solve itself. Instead, it has become an issue that needs an economic, political, social and technological struggle. Destroying the forests, animal migration, and the inaccessibility of clean air and drinkable water affect the natural balance to a great extent for the desire of human comfort and social facilities. These actions which distances even humans' life from sustanibility tranforms harmony between human and ecology to disharmony.

The fact that human beings, like all living things, depend on nature at the stage of existence, constitutes the basis of human-nature interaction. Humans and all living things, who have to adapt to the temporal changes of nature and the environment and live under these conditions maintain their existence in a continuous relationship with nature as a result of this adaptation. This obligatory situation ensures the continuity of the human's needs and predictions by trying to center her own situation (Sümer ve Diğerleri, 2020, s.2). In this sense, the wide-ranging technological developments that occur around the world affect human life and cause the world to become a village. In the light of these developments, the reduction of natural resources, the depletion of the ozone layer, rapid population growth, air and water pollution and similar situations, taking into account some global problems that may adversely affect people by consumers reveal their concerns about the future and the quality of life they want to achieve (Özkaya, 2010, s.256). 
Based on these concerns, the concept of anthropocene, which suggests that humanity causes serious and permanent environmental problems in the world, although it was used in the first half of the 20th century, has historically been adopted in the field of media and politics after 2000. The time elapsing between the scientific acceptance of the anthropocene-centered environmental problems and the acceptance of the concept in the society takes its place in a social construction phase that is also seen in other environmental problems (Eryılmaz, 2018, s.211). Political and ecological debates on the agenda about how to adapt to or mitigate the effects of changes and transformations that occur during this construction phase; It raises environmental problems such as the biogeochemical metamorphosis of the composition of the soil, ocean and atmosphere, which has led to many destructive ecological changes such as the extinction of living creatures caused by environmental destruction and the loss of habitats, the expansion of ocean dead zones, ocean acidification and global warming (Demos: 2017, s.8-9).

Today, environmental problems are encountered in individual and social life at a perceptible rate. Societies and individuals as consumers realize that environmental resources to sustain their lives are gradually decreasing due to environmental problems. As a result, consumers who have been aware of their environmental responsibilities emerge (Kükrer, 2012: 4506). In order to eliminate these concerns of consumers, it becomes a necessity for businesses to transform their production activities and practices into a more environmentally friendly manner within the framework of social responsibility. In this sense, it is very important for business managers to quickly reveal their view of the ecological environment in the form of change and to see the ecological environment as an important factor affecting decisions while making decisions related to planned activities (Özkaya, 2010: 256).

Because environmental problems gain social legibility and the corporations have responbilities to the society in which they reside, it is essential for the corporations targeting their marketing strategies to this line. With the extension of pollution in the world, it is observed that there has been an increase in the number of both the sustainability of marketing concept and consumer who prefers sustainability consumption. In the study, the responsibilities of businesses that are sensitive to the environmental problems of the world in the context of the anthropocene concept will be discussed and how the billboards, one of the public relations tools, are evaluated in terms of contributing 
to the green will be examined. Used as a public relations tool, what does billboards contain in terms of green environment, how do they contribute to the environment, how do they give a message, these questions will be answered by making a semiotic analysis. In the context of the study, environmentalist billboard works of brands such as Peru Technical University, Calidda Gaz firm, Toyota and Coca Cola will be examined within the scope of the subject.

\section{Kaynakça / References}

Akdağ, M. (2007). Halkla ilişkilerde sosyal sorumluluk, tüm yönleriyle halkla ilişkiler ve tanıtım Edt. M. Işık, Eğitim Kitabevi, 207-231.

Akdağ, M. (2010). Örgütsel açıdan insan kaynakları ve halkla ilişkiler. Literatürk Yayınlanı, Konya.

Aydoğan, S. ve Dinar, N. (2019). Yeşil ürün satın almada yeşil reklam ve çevre bilincinin etkisi. Akademik Sosyal Araştırmalar Dergisi, 90, 229-252.

Aytekin, P. (2007). Yeşil pazarlama stratejileri. Celal Bayar Üniversitesi Sosyal Bilimler 5(2), $1-20$.

Ayyıldız, H. ve Genç, K. Y. (2008). Çevreye duyarlı pazarlama: üniversite öğrencilerinin çevreye duyarlı pazarlama uygulamaları ile ilgili tutum ve davranışları üzerine bir araştırma. Atatürk Üniversitesi Sosyal Bilimler Enstitüsü Dergisi, 12(2), $505-527$.

Crutzen P.J. and Stoermer, E.F. (2000)., The Anthropocene. http://www.igbp.net/download/18.316f18321323470177580001401/1376383088452/NL41.pdf, adresinden erişilmiştir.

Curtin, B., (2009). Semiotics and visual representation, international program in design and architecture, http://www.arch.chula.ac.th/journal/files/article/lijpgMx2iiSun 103202.pdf, adresinden erişilmiştir.

Çetin, F. A., ve Korucuk, N. (2018). Yeşil pazarlama bağlamında yeşil tüketici davranış: Starbucks örneği. Sosyal Bilimler Dergisi, 5(22), 78-89

Demos, TJ (2017). Aganist the Anthropocene: Visual culture and environment today. https://icamiamiorg.storage.googleapis.com/2017/06/dc83ec96-mirzoeff-demos anthropocene-proofs-jan2017. pdf, adresinden erişilmiştir.

Donanım Haber. (2011). Donanım Haber. Coca-Cola'nın karbondioksit emme özelliğine sahip yeni reklam panosu Filipinler'de kullanilmaya başlandr: https://www.donanimhaber.com/CocaColanin-karbondioksit-emme-ozelligine-sahip-yenireklam-panosu-Filipinlerde-kullanilmaya-baslandi-27474 adresinden alınd 1 
Durgun, H. C., (2013). UTEC'ten dikkat çekmenin püf Noktalar, 15 Mart 2013 tarihinde Pazarlamasyon.com: https://pazarlamasyon.com/utecten-dikkat-cekmeninpuf-noktalari/ adresinden alındı.

Erbaşlar, G. (2012). Yeşil pazarlama. Mesleki Bilim Dergisi, 1(2), 94 - 101

Eryılmaz, Ç. (2018). Antroposen kavramının toplumsal inșası: Nesnel bilim, popuiler kuiltür ve çevreci politika. Doğu Batı Dergisi, 83, 211-237

Fidan, B. (2007). Reklam ve karikatür. İstanbul: Yazın Matbaacllı.

Fiske, J. (2003). Iletişim çalışmalarına giriş. Çev. S. İrvan, Ankara: Bilim ve Sanat.

Gürüz, D. (1993). Halkla ilişkiler teknikleri. Ege Üniversitesi İletişim Fakültesi Yayınları No.1, İzmir

Hamilton, C. (2016). Define the Antropocene in terms of the whole earth, https://www.nature.com/news/define-the-anthropocene-in-terms-of-thewhole-earth-1.20427 adresinden erişilmiştir.

Haraway, D. (2015). Anthropocene, capitalocene, plantationocene, chthulucene: making kin. Environmental Humanities, 6, 159-165.

Koçoğlu, C.M. ve Koçoğlu, Y. (2017). Yeşil pazarlama kapsamında çevreye duyarlı ürünlerin satın alma eğilimleri: Lisans düzeyinde turizm eğitimi alan öğrenciler üzerinde bir araştırma. Uluslararası Yönetim İktisat ve İşletme Dergisi, ICMEB17 Özel Sayısı, 417-427.

Kuzucu, B. N. (2018). Türkiye'deki yeşil reklam uygulamalarmm tüketicilerin çeoreci satın alma kararlar üzerine etkisi. Selçuk Üniversitesi Sosyal Bilimler Enstitüsü, Yüksek Lisans Tezi, Konya.

Kükrer, Ö. (2012) Tüketicilerin çevresel sorumluluklarının yeşil reklamlara yönelik tutumlarına etkisi: Eskişehir örneği. Journal of Yasar University 26 (7) 4505 4525 .

Moran, B, (2002). Edebiyat kuramları ve eleştiri. Iletişim Yayınları.

Özdönmez, M- Akesen, A ve Ekizoğlu, A. (1999) Halkla İlişkiler. İstanbul Üniversitesi Yayın No: 4225, İstanbul.

Özkaya, B. (2010). İşletmelerin sosyal sorumluluk anlayışının uzantısı olarak yeşil pazarlama bağlaminda yeşil reklamlar, Öneri 9(34). 247-258.

Pazarlamasyon.com., (2018). Hava kirliliğine dikkat çeken yaratıc billboard örnekleri, https://pazarlamasyon.com/hava-kirliligine-dikkat-ceken-yaratici-billboard-ornekleri//adresinden erişilmiştir.

Peltekoğlu, Filiz B. (2018). Halkla Illişkiler Nedir. İstanbul: Beta Basım Yayım Dağıtım.

Rumman, H., \& Valenzuela, F. (2016). Customer perception of green advertising in the context of eco-friendly FMCGs. Contemporary Management Research, s. 169-182. 
Starbucks (t.y). Sorumluluk Sahibi Bir Şirket Olmak. https://www.starbucks.com.tr/, adresinden erişilmiştir.

Sümer Ö., Alak A. ve Tekin A. (2020). Antropojen ve Antroposen kavramlarının tarihsel gelişimine yerbilimsel bir bakış. Türkiye Jeoloji Bülteni 63, 1-20

Şeşen, E. (2015). Çevre eğitiminde kamusal halkla ilişkiler ve stk'lar ile işbirliği, Selçuk İletişim, 9 (1), 429-443

Tarakçı, İ. E., Göktaş, B. (2019). Pazarlamanın yeni rengi: Yeşil Aklama Üçüncü Sektör Sosyal Ekonomi Dergisi 54(3) 1095-1113.

Tayfun, N. Ö. ve Öçlü B. (2015). Yeşil pazarlama uygulamasının tüketiciler açısından algılanmasının nöropazarlama tekniği ile araştırılması. Uludağ Üniversitesi İktisadi ve İdari Bilimler Fakültesi Dergisi, XXXIV (2), 95-113.

Tellan, D. (2015). Pazarlama iletişimi ekseninde çevrecilik: Yeşil kurum, marka ve halkla ilişkiler. Atatürk İletişim Dergisi, 9, 77-89

Turan. F. (2014). Çevre dostu şirketler: Yeşil göz boyama mı çevresel üretim mi?, Hacettepe Üniversitesi Sosyolojik Araştırmalar E-Dergisi, 1-26.

Ünal, B., (2019). Antroposen ve yeni dünya tasarıları, Fine Arts (NWSAFA), 14(3):186199

Yücel, H., (2016). Metin Çözümlemeleri. (Der. Yasemin G. İnceoğlu, Nebahat A. Çomak) Groupe u Edelin, Klinkenberg, Minguet İçinde,Ayrıntı Yayınları, İstanbul.

\section{Kaynakça Bilgisi / Citation Information}

Akdağ, M. ve Özdemir, M. (2020). Çevreye duyarlilik ve sorumluluk bağlaminda yeşil halkla ilişkiler ve antroposen kavrami: Billboardlar üzerinden bir göstergebilimsel analiz. OPUS-Uluslararası Toplum Araştırmaları Dergisi, 16(Özel Say1), 3505-3532. DOI: 10.26466/opus.791359 